This item was submitted to Loughborough's Research Repository by the author.

Items in Figshare are protected by copyright, with all rights reserved, unless otherwise indicated.

\title{
The changing organizational structure of football clubs and their relationship
} with the external media

PLEASE CITE THE PUBLISHED VERSION

http://journals.humankinetics.com/ijsc

\section{PUBLISHER}

(c) Human Kinetics, Inc.

VERSION

VoR (Version of Record)

LICENCE

CC BY-NC-ND 4.0

\section{REPOSITORY RECORD}

Cleland, Jamie. 2019. "The Changing Organizational Structure of Football Clubs and Their Relationship with the External Media”. figshare. https://hdl.handle.net/2134/12132. 


\title{
The Changing Organizational Structure of Football Clubs and Their Relationship With the External Media
}

\author{
Jamie A. Cleland \\ Staffordshire University, UK
}

\begin{abstract}
The development of "new" media and the financial investment in football since the early 1990s have dramatically changed the football club-media relationship. A number of clubs changed ownership and organizational structure for financial gain or financial survival while the increasing demand for immediate information led to clubs' recognizing the importance of external communication. Drawing on 47 semistructured interviews with media personnel and 827 questionnaires completed by supporters at 4 football clubs, this article assesses the organizational structure of clubs in dealing with the media and supporters and the level of dependence between clubs and the external media. The results highlight changes in the organizational structure of clubs and their strategies for external communication, as well as the contrasting relationships between football clubs and the external media. As ownership and personnel changes occur, clubs should remember the importance of the 2-way relationships they are in with supporters and the media.
\end{abstract}

Keywords: ownership, communication, interdependence

During the 1980s, unprecedented events occurred in football. Those in the media were arguably the most dramatic. What initially began with increasing coverage given to football by terrestrial television ended with the remarkable escalation of what Boyle and Haynes (2004) term "new" media (satellite television, the Internet, and mobile phones) and the way they (particularly satellite television) began to view football as a marketable commodity. Perhaps not surprising, the new media changed the political economy of football and helped make it an ever more important part of popular culture, stimulated by large levels of coverage and exposure. This also produced a more competitive media environment, with many "older" sources (such as newspapers and radio) forced to react to the market pressure created by "newer" ones.

In this respect, I shall argue that the development of new media has affected the level of dependence (or "interdependence") between old and new media and football clubs playing at different levels of the professional game. Although it could be suggested that some media sources are more dependent on clubs than vice versa, 
the term interdependence is used in this article where equal dependence occurs between external media sources and football clubs. ${ }^{1}$

It is not surprising that changes in the media also affected football clubs. At the elite level, clubs became larger organizations through investment linked to the Premier League (formed in 1992) and the subsequent redistribution of money through television broadcasting. This resulted in clubs at all levels altering their organizational structure, but in various ways. A number of the bigger clubs followed the example of Tottenham Hotspur (it floated in 1983) and floated on the stock market for the perceived financial reward that it initially offered, but, at the lower levels, Supporters' Trusts were developed, often for financial survival (Football Governance Research Centre, 2005; Hamil, Michie, Oughton, \& Warby, 2001). This led to many clubs changing the way they communicated externally, often resulting in their employing press or media officers to deal with the increasing demands on clubs for news and information and access to players and managers. It also created more of a commercial focus as clubs examined ways of broadening revenue streams, leading to a more professionally oriented organizational structure through the appointment of a chief executive and/or marketing or commercial directors.

Subsequently, this article examines the club-media relationship at four professional football clubs (Aston Villa, Birmingham City, Coventry City, and Northampton Town). To do this I have two objectives: to examine the organizational structure of each club in dealing with supporters and the external media and to analyze the level of dependence between each club and the external media. For the purposes of this article, external media refers to media sources that fall outside of clubs' control, such as the local and national media.

Overall, this article adds substantial value to the club-media debate. Wider research refers to an increasing level of interdependence between satellite television and Premier League clubs, particularly through the increasing importance of broadcasting revenue over gate revenue (Buraimo, Simmons, \& Szymanski, 2006; Deloitte \& Touche, 2008), but this is not directly stipulated. Furthermore, limited attention has been paid to the changing relationship between clubs and the local press (at all levels) and the increasing importance of club employees to improve external communication (Football Research Unit, 1999). Finally, in terms of the impact the media have had on clubs, again much research focuses on the changing ownership and organizational structure of clubs at the elite level, rather than through the game as a whole (Gannon, Evans, \& Goddard, 2006). This article builds on all of these areas, examining all levels of professional football.

\section{The Changing Club-Media Relationship}

This article describes how the modern club-media relationship revolves around two notable developments. The first is how the political economy of football began to change during the 1980s but rapidly gathered pace after the formation of the Premier League in 1992. Historically, an interdependent relationship existed between the local newspaper and the local football club, as the local newspaper relied on the interest generated in clubs to increase sales and clubs relied on the local newspaper to provide regular communication with supporters. More recently it could be argued that this interdependence has now expanded to satellite television because of the 
investment and coverage it provides to clubs (mostly those in the Premier League) and the need for it to generate profits through sales and advertising.

The second development is how this growing relationship led to changing patterns of ownership and external communication among clubs, most notably the bigger ones. Originally, throughout the 1990s, in addition to floating on the stock market, media companies began buying into certain clubs because it allowed them to be involved in negotiations for future television contracts and, as such, changed the relationship further, particularly at the elite level. However, this practice is now being replaced by wealthy overseas investors who are increasingly attracted to the English game. All of this has created a more professional approach in the way that clubs manage their external communication (such as with external media, fans, the local community, and shareholders), particularly when issues (like a crisis) arise and require immediate action.

The changing political economy of the club-media relationship can be traced back to the early 1980s. It began in 1983 when the first contract to show exclusive live matches was agreed between ITV, the BBC (initially it was shared jointly between the two major television broadcasters), and the Football League at an annual cost of $£ 2.6$ million. However, it really gathered pace in the early 1990s. First, British Satellite Broadcasting (BSB) merged with Sky in 1990 (creating BSkyB), and second, a new Premier League was formed, to begin in 1992.

These two changes led to the loss of live matches on terrestrial television, with BSkyB winning the exclusive rights over a rival bid from ITV for a 5-year contract worth $£ 304$ million to start broadcasting live Premier League matches from August 1992. This decision fundamentally changed both the economics of English football and the club-media relationship as clubs in the Premier League realized the financial windfall such an agreement would bring. In fact, this relationship continued throughout the 1990s and the early years of the twenty-first century, with the next three available contracts for exclusive rights to Premier League matches all purchased by BSkyB. ${ }^{2}$

However, the monopoly held by BSkyB on the live coverage of English Premier League matches changed when the 2007-2009 broadcasting rights became available after intervention by the European Union, who argued that the broadcasting market in England was anticompetitive. To try to combat this ruling, the Premier League split the live coverage of matches into six separate packages and invited bids from rival broadcasters for each of them. BSkyB eventually won four and paid $£ 1.31$ billion to broadcast 92 more desirable live matches a season, with the Irish pay-TV group Setanta initially purchasing the other two for $£ 392$ million, showing 46 games a season. Including the highlights rights paid by the BBC (£171.6 million) the total cost of these rights was $£ 1.706$ billion, a $30 \%$ increase from the last contract (Dowell, 2006). Therefore, even though BSkyB lost its complete exclusivity, it is very much evident that it is still the major force in broadcasting top-level English football because of the packages it purchased and the number of games it will broadcast.

In trying to compete with BSkyB, a number of television broadcasters overinvested and as a consequence seriously affected their relationship with football clubs. For instance, media companies such as NTL, ITV Digital, and, more recently, Setanta have found that they could not maintain the financial outlay they had originally promised. NTL paid $£ 328$ million in 2000 for 44 Premier League games a 
season on pay per view, but within weeks of the 3-year deal being announced it had to withdraw because of financial problems. Similarly, in June 2000 ITV Digital paid $£ 183$ million for a 3-year deal with the Football League, but it also had to withdraw less than a season into the contract. In June 2009, Setanta fell into financial difficulties, with the company missing payments to both the English Premier League and the Scottish Premier League. This led to the American TV sports network ESPN purchasing the rights to screen 46 live matches in the 2009-10 season and a further 23 games a season for 3 years in a hastily arranged auction.

Because of the increasing coverage provided by the media (mostly to the Premier League) there has been an increasing focus on the developing club-media relationship, but whether they share an interdependent relationship has largely been overlooked. This relationship has clearly opened up an opportunity to target new audiences and has transformed the game into a global phenomenon. In fact, it could be argued that the relationship between top-flight football clubs and BSkyB has become one of interdependence. This can be seen with the breakdown of revenue for Premier League clubs in the 2006-07 season: 39\% from broadcasting, 35\% from match-day revenue, and $26 \%$ from commercial/sponsorship revenue (Deloitte \& Touche, 2008). ${ }^{3}$

Deloitte and Touche (2008) provide a further striking example of the developing interdependent relationship between BSkyB and the Premier League: The average annual turnover of a Premier League club is 6 times greater than that of a Championship team. Furthermore, Buraimo et al. (2006) found that the Premier League's share of revenue from 1993/94-2002/03 was 74\%, compared with 18\% in the new Championship Division. Therefore, the clubs playing in the Premier League are significantly bigger in terms of fan base, coverage, stature, and finance than those playing in the Football League and thus are more likely to be a target for future investment. In this context, the financial rewards on offer for playing in the Premier League are one reason why promotion is vital for the clubs who play in the Championship, with the playoff final viewed as the most lucrative game to win in club football across the world.

In a way similar to what has been argued about television coverage, teams outside the top division in the UK have historically not received a lot of coverage in the national media because of their lower profile. Therefore, it is likely that lower league clubs and their main local newspaper still share an interdependent relationship. This is not to say that other local media sources are not important-the more interest they can provide to local sports, the more people will listen to local radio and watch local television. Similarly, lower league clubs need the exposure and coverage provided by the local media to maintain interest and encourage people to attend matches on a regular basis.

As the club-media relationship continues to grow (mostly at the elite level), another development in this relationship centers on the changing patterns of ownership in some clubs. In the 1990s, a range of media companies including BSkyB, Granada, and NTL invested in clubs because it allowed them to be involved in negotiations for future television contracts. ${ }^{4}$ However, as the Monopolies and Mergers Commission report into the proposed takeover of Manchester United by BSkyB in 2002 outlined, media-company ownership of football clubs raises public concerns about the future of the game. It would be no surprise that if rights were sold individually it would benefit the bigger clubs and increase the gap further with the smaller clubs in the Premier League and also the Football League. 
In this complex and constantly changing environment, some of these media companies have now sold some of the shares they held in certain clubs (Gannon et al., 2006; O'Connor, 2004). Examples of this include BSkyB's selling its 9.9\% stake in Chelsea and writing off a $£ 40$ million investment it made in the club in 2000 and also selling its $9.9 \%$ stake in Manchester United for $£ 62$ million in October 2003. However, it would be wrong to assume that media corporations are no longer interested in football clubs, because the developments in new media continue to maintain BSkyB's influence at a number of clubs, including Chelsea, where it remains a key media partner. Furthermore and again highlighting the changing environment, recent research carried out by Deloitte and Touche (2008) found that at a peak, 20 clubs were listed on the stock market (either the London Stock Exchange or the Alternative Investment Market), but this has subsequently decreased to only 7 .

The idea of floating on the stock market seems to be fading, and it has been argued that it is better for clubs to have one wealthy owner or benefactor to finance them (Buraimo et al., 2006; Horne, 2006). This seems to be the case with, for example, Roman Abramovich at Chelsea, Malcolm Glazer at Manchester United, and Randy Lerner at Aston Villa, all recently buying into their respective football clubs. This reflects the constantly changing picture of ownership at top-level clubs, with media-corporation ownership being reduced and replaced by ownership by wealthy individuals whose financial input easily makes them majority shareholders.

Because of the developments described here, especially the prominence of the media as an actor in the industry, there is a more professional approach in the increasing levels of external communication emanating from clubs. Clubs now view corporate communications as important, such as dealing with their shareholders, the local community, and the general day-to-day queries that arise from supporters, but a key test of their communication strategy arises when there is a crisis that requires immediate attention. When a crisis does occur there is a need to modify, as far as possible, the negative affect it has on the club to protect both its key stakeholders and its long-term future (Caywood, 1997; van Riel, 1995). According to Thill and Bovée (1993), two communication philosophies are available: say nothing or tell all and tell it fast. Each club's use of media sources becomes vitally important at this point: If it copes well with any crisis, its image should be quickly restored, but if it fails, its reputation and potential profitability could be damaged.

In summarizing the literature on this area and taking the debate forward, a number of questions have arisen that this article now assesses:

- Can the size of a club affect its relationship with the external media?

- What effect has the increase in media sources had on the interdependent relationship between each football club and its local evening newspaper?

- What effect has the increase in media sources had on the number of club employees responsible for external communication?

- To what extent is the local press now more dependent on football clubs because of the increasing levels of competition in providing news and information to supporters?

- What impact has the development of new media had on the relationship between a football club and the external media? 


\section{Method}

The methods of data collection and analysis adopted for this article were part of wider research that also examined the club-fan relationship and the media-fan relationship. Four football clubs-Aston Villa, Birmingham City, Coventry City, and Northampton Town - were used to collect the necessary data. These four clubs were selected because they had different levels of ownership (Aston Villa was "listed" between 1997 and 2006 and Birmingham City has been listed since 1997), different numbers of club employees responsible for external communication, and different profiles in the wider external media.

To analyze the club-media relationship, a multimethod approach combining both qualitative and quantitative methods was employed. Once consent had been obtained, 47 in-depth semistructured interviews with relevant club officials (those involved in the communication process), unofficial external personnel (fanzine editors, unofficial Web site editors, and supporters' group representatives), and local media personnel (local journalists involved in newspapers, radio, and television) were conducted. The questions centered on two main themes, both of which focused on the two research objectives: the organizational structure of clubs in dealing with the external media and supporters and the relationship they have with the club/external media (depending on whether they were employed by the club or had an external role).

To support the qualitative interview data, a more quantitative questionnaire was also employed to collect a larger breadth of data from supporters at each club. While it also helped to assess the media-fan and club-fan relationships, the club-media aspect of the questionnaire focused on four main questions, the last of which was left "open" for supporters to provide feedback to clubs:

- How did fans rank the different media sources in terms of importance?

- Did fans feel that the club provided them with enough information?

- Did fans feel that the club communicated well with them?

- In what ways did fans think the club could improve communication with them?

The interviews were analyzed through a manual form of content analysis. Although content analysis can be used quantitatively to count themes numerically, each subject's responses were coded and categorized, thus providing more depth to the research. As suggested by Miles and Huberman (1984), once all the data had been themed into categories, the analysis began to identify "patterns and processes, commonalities and differences" (p. 9) across all four clubs.

With regard to the fan survey, 827 questionnaires were completed. They were analyzed using SPSS to, first, develop a visual distribution of the data and, second, develop cross-tabulations to identify patterns and make comparisons. During the data collection, close attention was paid to make sure each response to the open question was recorded exactly as it was given, with no attempt at summarizing or making grammatical corrections (as suggested by Babbie \& Mouton, 2001). In fact, some fans provided quite a lot of feedback covering many different aspects of communication, and this was taken into account when the coding of their responses was carried out. Once all the questionnaires had been collected each response on the open question was then coded into 14 themes and entered into SPSS for analysis. Themes 1-4 were coded as fan responses, 5-11 were coded as media/communication responses, and 12-13 were coded as club responses: 
0 . No response to question.

1. Listen to the fans.

2. Respect the fans.

3. More fans' forums.

4. Have a fan on the board.

5. Have a regular newsletter/personal correspondence.

6. Keep fans better informed.

7. Use national/local media better.

8. Improvements with Web site.

9. Improvements with match-day program.

10. Have a TV channel.

11. Improvement is good/communication OK.

12. More honesty and openness.

13. More community focus.

\section{Case-Study Findings}

In his analysis of English football's ownership and financial structure, Morrow (1999) developed a characterization of football companies by defining three "types": concentrated ownership (where one or a few individuals or institutions own a large percentage of shares), diversified ownership with concentrated control (where one or a few dominant shareholders exert effective control), and diversified ownership (where shareholding is diverse). In adapting Morrow's typology, the four clubs in the current study represented different ownership types and between them played in three different divisions of English football. However, the complexity of clubownership categories is put into perspective because of the rapidly changing nature of this environment; all four clubs had either been taken over or had come very close to it over the 4-year period from 2003 to 2007.

From 1997 to 2006 Aston Villa was a listed club, and it has continuously played in the Premier League since its inception in 1992. Pre-August 2006 the club would have been classified as diversified ownership-concentrated control, because Doug Ellis owned 38\% of the shares and Jack Petchey owned 20\%. This changed, however, in August 2006, when Aston Villa was taken over by a foreign investor (Randy Lerner) and changed its ownership type to concentrated ownership because of the majority shareholding Lerner quickly acquired.

Birmingham City has been a listed club since 1997 and has played in both the Premier League and the Championship Division of the Football League in recent seasons. It would be classified as diversified ownership_concentrated control as a result of the shares owned by Ralph and David Gold, David Sullivan, and more recently foreign businessman Carson Yeung. In fact, the club came close to selling to Yeung in 2007 when he bought a $29.9 \%$ stake in the club. Although no takeover materialized at the time (Yeung has kept his shareholding), it again highlights how close some clubs can come to changing ownership, especially those that are in the most exposed football league in the world. 
On the other hand, Coventry City is an "unlisted" club and since the 2001/02 season has played in the Championship. From 2003 to December 2007 the club would have been classified as concentrated ownership because Geoffrey Robinson owned $62 \%$ of the shares. However, in December 2007 the club was taken over by a London-based investment company called SISU 30 minutes before it was due to go into administration but maintained its concentrated-ownership classification as a result of the company's quickly acquiring over $90 \%$ of the club's shares.

Northampton Town is also an unlisted club, and even though its ownership and organizational structure have included its Supporters' Trust since the early 1990s, it remains faced with many difficult decisions because of its lower league position. ${ }^{5}$ In 2002, the club found itself in a precarious financial position and launched an SOS (Save Our Season) appeal to its supporters to generate $£ 500,000$ by the end of January 2003 to pay off money owed to creditors and avoid going into administration. In December 2002, the club felt it had found its financial savior when Andrew Ellis took over from outgoing chairman Barry Stonhill. However, Ellis only lasted 2 months in charge, and the club's future was only secured when a consortium led by David and Tony Cardoza acquired majority shareholding and in doing so paid off some of the club's long-term debt. Although the Supporters' Trust maintained its shareholding, this change of ownership moved the club from diversified ownership_-concentrated control to concentrated ownership.

Because of the size and scope of each organization, it is not surprising that there were differences in the number of personnel employed to deal with external communication. Both Aston Villa and Birmingham City had either a media officer or a press officer who managed their local and national external communication, each of whom was also supported by individuals who had specific responsibilities in the communication chain such as an official Web site editor and a match-day program editor. Aston Villa had the largest number of internal employees solely responsible for communicating with the media and its supporters (six), whereas at Birmingham City three internal employees were solely responsible for maintaining its external communication.

In contrast, at the unlisted clubs a different strategy for external communication was noticeable, with most employees found to have diverse and nonspecific job descriptions. Although Coventry City employed a press officer to oversee its external communication, she was also responsible for some of the content on the official club Web site. This was not surprising because the size of the club and its lack of finances had created the need for diverse job roles, and although the club still had to communicate with its shareholders, it understandably had more of a local rather than national focus with the distribution of information.

At Northampton Town, and somewhat expected because of its lower league status and financial position, only two employees were responsible for managing the whole of its external communication. In fact, the media officer stated that the club has one of the smallest internal workforces (10 administrators covering all aspects of the club) in the whole of professional football. Consequently, its main focus when distributing information was often local, rather than national.

From assessing each club's organizational structure and the increasing pressure put on external communication by the media and supporters, it could be suggested that there are four "types" of function for a club's media or press officer: 
- Develop a positive image of the club and its brand.

- Provide information to fans and the external media.

- Develop a two-way relationship with fans by involving them in the club.

- Manage any crises that arise with as little damage and disruption to the club as possible.

With regard to the second and third functions, across all four clubs the results of the survey illustrated how they could improve their level of external communication. For example, at Aston Villa and Coventry City only half of those surveyed felt their club communicated effectively with them, while just over half indicated they were happy with the amount of information they received. The open-question comments for both clubs also centered on the "fan" and "club" themes, including the need for more openness and honesty and more fans' forums to let supporters have their say. The results were better at Birmingham City, where nearly three quarters of supporters felt the club communicated effectively with them and provided them with enough information. Again, the club theme was raised in the survey, with a number of supporters arguing for more openness and honesty. Finally, at Northampton Town just over three quarters of supporters felt the club communicated effectively with them and were happy with the amount of information they received. However, all three survey themes were raised at this club, with supporters arguing for more openness and honesty and to keep fans better informed, possibly as a result of the financial troubles the club faced. The small number of employees and scope for external communication were also highlighted, with some supporters feeling that the club could use the external media better and not rely on its internal media sources.

Naturally, the press or media officers provided a positive image, but each had to deal with a crisis during the research process. On the sacking of first-team manager Graham Taylor in 2003, Aston Villa acted very quickly in naming David O'Leary as its new manager, while a similar situation arose at Birmingham City through the crowd disturbances that marred both local derby matches with Aston Villa during the 2002-03 season and the failed takeover by Carson Yeung in 2007. In 2003 the publication of the large debt affecting Coventry City ( $£ 60$ million) led the newly appointed chairman at the time, Mike McGinnity, to improve the club's relationship with the external media (particularly the local press), and again in 2007 a crisis occurred when the club fell within 30 minutes of administration. Similarly, at Northampton Town, the publication of another financial crisis in 2002-03 led to the local and wider community contributing to its survival as a professional football club. This all confirms the suggestions by Caywood (1997), Thill and Bovée (1993), and van Riel (1995) that clubs should act quickly when a crisis arises.

To provide an illustration of how the local media report crises or opportunities at clubs, Aston Villa is a good example. When reviewing the content surrounding the departure of the first-team manager, Graham Taylor, at the end of the 2002-03 season in the local press, it was clear how much criticism was raised at the way the club communicated externally. In the local morning newspaper, the Birmingham Post, the chief football writer Hyder Jawad (2003a) wrote,

Since releasing a statement to announce Taylor's departure, members of the Villa board have refused to discuss key issues at the club. The wall of silence has added to the frustration of supporters, many of whom are anxious for 
regime change at Villa Park. . . . No club in the Premiership has a more bruised relationship with its supporters than Villa. (p. 36)

The very next day, Jawad (2003b) was again highly critical of the club's communication strategy under Doug Ellis: "In the real world, the masses are calling for regime change. Aston Villa know this but are doing what they always do in times of distress: they put their fingers in their ears and keep their mouths shut" (p. 33).

However, and unknown to the local and national media, the club acted very quickly in appointing David O'Leary as manager and by doing so was seen to manage the crisis to its advantage. For instance, Jawad (2003c), somewhat begrudgingly it seemed, admitted,

It is not often that Aston Villa succeed in disarming their critics but they did so adroitly on Tuesday afternoon. Announcing O'Leary as their new manager was a masterstroke in public relations and a message to supporters that, yes, everything appears to be under control. . . By lowering expectations, the club was able to emerge with O'Leary and win the propaganda battle. (p. 38)

In highlighting the fluctuating club-media relationship further, even though the local media spoke for the majority of fans in stating their approval of the takeover by Randy Lerner in 2006, Lerner was occasionally criticized. For instance, only 4 months after his appointment Murphy (2006) stated,

It would be a timely opportunity for Randy Lerner to communicate his aspirations and vision to the Villa fans. But we wait in vain. Since he took over in August, he has blocked all attempts from the media to engage in dialogue with us and, by extension, the fans. There are no signs that he plans to do so. That's a pity, because his one and only press conference at Villa Park would have been the easiest he would ever have had to face. He has lost a great chance to enthuse the supporters, whose goodwill towards him after buying out Doug Ellis was massive. (p. 27)

One possible reason that close attention is paid by clubs to external communication is the increasing number of media (especially new) sources involved in football. Not only did they speed up the availability of news and information but they also created a competitive media environment, forcing older sources such as newspapers and radio to strategically react. Therefore, despite suggestions by Sage (1998) that media organizations have no inherent interest in sport, it could be questioned whether the proliferation of a range of different sources has made the relationship between football clubs and the external press interdependent. This has been a result of the debate surrounding the "new business of football" (as suggested by Bower, 2003; Dobson \& Goddard, 2001; Morrow, 2003) as clubs became dependent on the money and exposure generated through the developing relationship with television (most notably BSkyB).

This became clear both during the interviews and after analyzing the survey data. For example, the rapid development in media sources had taken away the previous exclusivity granted to local television and local radio. All the local television journalists who were interviewed stressed a dependence on clubs to provide them with news and information for their bulletins; some of them just took information 
off each club's official Web site rather than speaking to the press or media officer. Radio's importance as a local service provider was more apparent with the exclusive commentary deals they were involved in. At Birmingham City, Capital Gold/BRMB Radio held the commentary rights to all the club's home and away matches, as did BBC Radio Coventry and Warwickshire at Coventry City. At Aston Villa, Capital Gold/BRMB Radio held exclusive commentary rights on all away matches and five home matches of its choice, with BBC Radio WM holding the rights to the other 14 home matches. However, at Northampton Town, BBC Radio Northampton did not provide commentary on every football match because of the local interest in Northampton Saints Rugby Club. Rather, the radio station focused on the team playing away from home, arguing they could thus serve the biggest audience. As a consequence, the BBC Radio Northampton sports presenter indicated that his radio station was dependent on the football club because

If I lose that relationship with the club trying to put my neck on the block taking a gamble for short term gain I do not think it's really worth it. . . . I won't suddenly come out with something on the radio that I haven't got clarified as fact.

The results for the local evening newspaper-club relationship suggested a continued interdependence. Despite a fall in newspaper sales, the importance of clubs' maintaining links with their local community through the local evening newspaper can be found in the respective sales. For example, figures released by the Press Gazette ("Regional ABCs," 2008) highlight how the Birmingham Evening Mail sold over 66,000 copies per evening, the Coventry Evening Telegraph sold over 46,000 copies per evening, and the Northampton Chronicle and Echo sold nearly 20,000 copies per evening. It is worth mentioning that these newspapers are also available online, with a large number of people choosing to read them in their own time rather than actually buying an evening edition.

The importance of the role played by the local evening newspaper as part of a club's external communication was also clear when the results of the fan survey were analyzed. When supporters were asked to name their single most important source of news and information on their club, at Aston Villa, Birmingham City, and Coventry City the local evening newspaper was named. This, therefore, supports the continuation of the historic interdependent relationship between clubs and the local newspaper. However, to highlight the growth of new media, the official club Web site was a close second in terms of importance for club news and information at those three clubs and was the most important at Northampton Town.

Although clubs now have their own internal sources of communication such as their official Web sites, match-day programs, mobile-phone texting, and other points of contact, across all four clubs the staff employed to deal with external communication all stressed the importance of a healthy relationship with the local media. For example, the head of media at Aston Villa stated that the local media were vital because "the working man's contact with the football club is essentially going to be through the local media . . that is for a lot of people the way that supporters will communicate or gain information perhaps more accurately with the football club."

Similarly, the match-day program editor at Aston Villa illustrated that the changing times in football and the media coverage the club received nationally 
made it less dependent on the local press than it was at one time, but he thought "they have got a crucial role to play" even at a club the size of Aston Villa. However, he did stress the importance of this relationship by stating that "the club need the media and the media obviously need the club . . . without the day-to-day stories on television, radio and newspapers the club would struggle to generate interest on their own."

Despite the occasional criticism of the club raised earlier, the interdependent relationship between the Birmingham Evening Mail and the club was clear, with the Aston Villa journalist employed by the Birmingham Evening Mail stating that "they need us and we do need them ... no question their partnership with us helps us. . . . [They] sell our papers definitely . . . they could make it bloody difficult for us by closing the doors completely."

At Birmingham City, again an interdependent relationship between the Birmingham Evening Mail and the club came through the interviews with the Web site editor at the club, who stated that the relationship was a "partnership [as] we'll try to help them and they will help us, it definitely is a two-way thing [as] they can't do their job without our cooperation and our job is more difficult without their cooperation."

Similarly, the press officer illustrated how he believed Birmingham City received more coverage in the Birmingham Evening Mail than Aston Villa or West Bromwich Albion, with the official Web site taking over as the main provider of news and information outside of its circulation area. These views were also stated by the match-day program editor, who acknowledged that the local evening newspaper was crucial to the club's longevity, because its wide circulation helped the club provide news and information to a large number of supporters.

Because of the lack of national exposure of lower league football, employees at both Coventry City and Northampton Town viewed the local press as crucial in providing as much coverage and exposure as possible. In fact, Coventry City's relationship with the local press had changed from a negative one when Bryan Richardson was chairman (pre-2003) to one where it recognized the importance of using the local press to communicate with its supporters better. The constant reference to a new "open and honest" approach to its external communication was well received by the local media, who began to be more supportive of the club as a result of club officials' being available for comment on a regular basis. Speaking at the press conference immediately after his appointment as club chairman in 2003, Mike McGinnity stated,

We've got to give 100 per cent honesty to our fans. They are the most important people at any football club. If we have support through the gate, and work together, the board in particular, and the management of the football team will succeed. (Turner, 2002, p. 2)

During the course of this research, it became apparent that there was a changing emphasis from Coventry City with regard to the relationship it had with external (especially local) media sources. For instance, after relegation from the Premier League, the commercial manager noted how the club's view of the local media had changed to one where it tried to support their activities and grant them "almost unfettered access." Similarly, the press officer outlined how "the local media are invaluable," and if they were to stop covering the club it would create a "large gaping hole. . . . We could 
end up losing a lot of support because people wouldn't have the resources to find any information out on Coventry City. . . . I think that could damage us a great deal."

Even though the local media are important at a club like Coventry City, the interdependent relationship between the club and the Coventry Evening Telegraph was also stressed by the local print journalist:

It's a two-way thing, they need us as much as we need them . . . the vast majority of people who buy the Evening Telegraph do so for the sport, so it is a huge thing for us but by the same token the club need the newspaper to spread the news and views and make the fans aware of what is going on.

Naturally, because of its position in professional football, the head of media at Northampton Town stated that the club worked closely with the local media to try to provide the widest profile for the club as possible. He also believed that because most of its support was more than likely local, the profile the club received in the local media was paramount to its survival. These views were supported when the Northampton Chronicle and Echo sponsored the SOS appeal issued by the club in 2002, with the local journalist covering the club also contributing a section in the match-day program. However, he could not be supportive all the time, because events on and off the field meant that articles perceived as negative by the club also had to be covered in order for the newspaper to retain credibility among its readers. This all helped support the continued interdependent relationship between the Northampton Chronicle and Echo and the club.

Nationally, the involvement of BSkyB has created an interdependent relationship with top-level football clubs such as Aston Villa and Birmingham City because of the exposure and financial investment made (Buraimo et al., 2006; Deloitte \& Touche, 2008). However, despite Coventry City and Northampton Town being more dependent on local rather than national media for regular news and coverage, because of the financial rewards available from BSkyB they are more dependent on BSkyB to broadcast their matches, because gate receipts would not be as high as those of Premier League clubs. As for the relationship between each club and the other external sources, the results of the survey and the in-depth interviews both highlighted that although they remained important, clubs were less dependent on them than vice versa (such as fanzines and unofficial Web sites).

\section{Conclusion}

This article has presented many changes in the club-media relationship. First, it outlined how quickly clubs can change their ownership and organizational structure; between 2003 and 2007 three clubs went through major organizational change, with Birmingham City coming very close to doing so. Second, it stated the importance of establishing external communication mechanisms to deal with the increasing demand for news and information from supporters and the media. To do this, three of the clubs had employed press or media officers. As the biggest clubs in this research, the roles for internal personnel in the communication process were clearer at Aston Villa and Birmingham City than at Coventry City and Northampton Town because the bigger clubs had more national exposure than those that competed outside of the Premier League. 
This article also illustrated the changing levels of dependence between the "old" and "new" media and clubs. Both the interview and survey data stressed the continuation of an interdependent relationship between the local evening newspaper and all four clubs, as well as between BSkyB and the clubs in the Premier League. They also highlight how the proliferation of new media has taken away some of the dependence on certain aspects of the local press. Although certain local radio stations had exclusive radio commentary deals with clubs and remained an important link between each club and its fans, their overall importance as a source for news and information has been affected. Equally, the once "cozy" relationship between local television and clubs has been affected by the desire for immediate news and information on football and has resulted in local television being more dependent on clubs than vice versa.

Finally, as the club-media relationship continues to evolve and ownership and personnel changes occur at clubs, the clubs need to remember that they are involved in two-way relationships with the media and with the fans and that these relationships demand appropriate management. As this article has indicated, this management has to be constantly responsive to changes in technology and popular culture. The dangers of not taking account of this have been clearly shown in the disastrous experiences of Newcastle United under Mike Ashley, maybe even Liverpool under George Gillett and Tom Hicks, and possibly also the negative publicity that the Glazers have incurred at Manchester United. These are all examples of media and fan relationships that have been badly handled by clubs and indicate that this is an ongoing and high-profile issue for club owners and managers.

\section{Notes}

1. In terms of media or society relations, it has been suggested that interdependency occurs where an equal relationship is found between the external press and social institutions (Coakley, 2003; O’Sullivan, Dutton, \& Rayner, 2003).

2. BSkyB paid $£ 670$ million for a 4-year contract from 1997 to $2000, £ 1.1$ billion for a 3 -year contract from 2001 to 2003, and $£ 1.1$ billion for a 3-year contract from 2004 to 2006.

3. In 1991-92, television revenue provided just 9\% of turnover (Robinson, 2007).

4. Media companies are not allowed by the Football Association to own more than $10 \%$ in a club because of their rule on dual ownership. If a media company owns less than $10 \%$ in a football club the Football Association will allow it as long as the shares are held for investment purposes.

5. The Supporters' Trust at Northampton Town was one of the first to be established and arose after the club fell into administration. To keep the club running, the Supporters' Trust paid $£ 105,000$ into the club from 1994 to 2001, accruing a 7\% share. In the process, this also led to them having a representative on the board of directors (Lomax, 2001).

\section{References}

Babbie, E., \& Mouton, E. (2001). The practice of social research. Oxford, UK: Oxford University Press.

Bower, T. (2003). Broken dreams: Vanity, greed and the souring of British football. London: Simon and Schuster.

Boyle, R., \& Haynes, R. (2004). Football in the new media age. London: Routledge. 
Buraimo, B., Simmons, R., \& Szymanski, S. (2006). English football. Journal of Sports Economics, 7(1), 29-48.

Caywood, C.L. (1997). The handbook of strategic public relations and integrated communications. New York: McGraw-Hill.

Coakley, J. (2003). Sport in society: Issues and controversies (8th ed.). Boston: McGraw Hill.

Deloitte \& Touche. (2008). Annual review of football finance. London: Deloitte \& Touche.

Dobson, S., \& Goddard, J. (2001). The economics of football. Cambridge, UK: Cambridge University Press.

Dowell, B. (2006, May 5). Premiership TV fetches £1.706bn. Guardian. Retrieved September 20, 2006, from http://www.guardian.co.uk/media/2006/may/05/citynews.broadcasting

Football Governance Research Centre. (2005). The state of the game: The corporate governance of football clubs 2005. Birkbeck, UK: University of London.

Football Research Unit. (1999). The sources of football information amongst Everton and Liverpool fans. Liverpool, UK: Liverpool University.

Gannon, J., Evans, K., \& Goddard, J. (2006). The stock market effects of the sale of live broadcasting rights for English premiership football: An event study'. Journal of Sports Economics, 7(2), 168-186.

Hamil, S., Michie, J., Oughton, C., \& Warby, S. (2001). The changing face of the football business: Supporters direct. London: Frank Cass.

Horne, J. (2006). Sport in consumer culture. Basingstoke, UK: Palgrave Macmillan.

Jawad, H. (2003a, May 16). Taylor: I took the heat off the board. Birmingham Post, p. 36.

Jawad, H. (2003b, May 17). Ellis turns Europe's best into irrelevance. Birmingham Post, p. 33.

Jawad, H. (2003c, May 22). Villa's fast one has disarmed critics and provided hope. Birmingham Post, p. 38.

Lomax, B. (2001). How democracy saved Northampton Town FC. In S. Hamil, J. Michie, C. Oughton, \& S. Warby (Eds.), The changing face of the football business: Supporters direct (pp. 102-110). London: Frank Cass.

Miles, M.B., \& Huberman, M.A. (1984). Qualitative data analysis. Thousand Oaks, CA: Sage.

Morrow, S. (1999). The new business of football: Accountability and finance in football. Basingstoke, UK: Palgrave Macmillan.

Morrow, S. (2003). The people's game? Football, finance and society. Basingstoke, UK: Palgrave Macmillan.

Murphy, P. (2006, December 19). Silent Lerner keeps missing open goal. Birmingham Post, p. 27.

O'Connor, A. (2004). City knocks football into touch. The Times (London, England), p. 53.

O'Sullivan, T., Dutton, B., \& Rayner, P. (2003). Studying the media (3rd ed.). London: Arnold.

Regional ABCs: MEN has top circulation but no dailies put on sales. (2008). Press Gazette. Retrieved June 12, 2009, from http://www.pressgazette.co.uk/story. asp? storycode $=42001$

Robinson, J. (2007, November 4). Screen grab. The Observer, p. 11.

Sage, G.H. (1998). Power and ideology in American sport (2nd ed.). Champaign, IL: Human Kinetics.

Thill, J.V., \& Bovée, C.L. (1993). Excellence in business communication (2nd ed.). London: McGraw-Hill.

Turner, A. (2002, January 31). Amazing board room war of words-In the end we had no choice; Sky Blues power struggle rivalry. Coventry Evening Telegraph, p. 2.

van Riel, C.B.M. (1995). Principles of corporate communication. London: Prentice Hall. 
Copyright of International Journal of Sport Communication is the property of Human Kinetics Publishers, Inc. and its content may not be copied or emailed to multiple sites or posted to a listserv without the copyright holder's express written permission. However, users may print, download, or email articles for individual use. 